\title{
Marital Quality: A Conceptual Review
}

\author{
Siti Rohmah Nurhayati ${ }^{1}$, Faturochman ${ }^{2}$, Avin Fadilla Helmi ${ }^{3}$ \\ ${ }^{1}$ Department of Psychology, Universitas Negeri Yogyakarta \\ 1,2,3Faculty of Psychology, Universitas Gadjah Mada
}

\begin{abstract}
The quality of marriage gain the attention of researchers for a long time. Various studies have been done, by placing the marital quality as an independent variable or dependent variable. Although research on marital quality has been done for a long time with a wide range of variables, conceptually, the results are not quite satisfactory. This article aims to describe literature review on the concept of marital quality. The literature search results define quality of marriage as the level of excellence in marriage based on certain characteristics. These particular characteristics or criteria may vary from region to region. The criteria for the quality of marriage may also differ from one period to another. The dimensions of marital quality vary widely, which can be distinguished into intrapersonal and interpersonal dimensions. Meanwhile, factors affecting the quality of marriage are differentiated into internal factors and factors related to the conjugal relationships.
\end{abstract}

Keywords: marriage; marital quality; dimensions of marital quality; predictors of marital quality

\section{Introduction}

Marital quality is a topic that receives great attention from marriage researchers (Norton, 1983; Fincham \& Linfield, 1997; Fincham \& Rogge, 2010; Fowers \& Owenz, 2010; Knapp \& Holman, 2010). The quality of marriage is examined and is associated with various other factors. Several studies have found that the quality is a determinant of well-being (Kim \& McKenry, 2002; Proulx, Helms, \& Buehler, 2007; Frech \& Williams, 2007; Ryan \& Willits, 2007), health (Bookwala, 2005; Umberson, Williams, Powers, Liu, \& Needam, 2006), job satisfaction (Rogers \& May, 2003), sleep disorders (Troxel, Robles, Hall, \& Buysse, 2007), blood pressure, stress, and

\footnotetext{
${ }^{1}$ Address for corespondence: siti_rohmah@uny.ac.id, faturpsi@ugm.ac.id, avinpsi@ugm.ac.id
}

depression (Holt-Lunstad, Birmingham, \& Jones, 2008; Kim, 2012).

Marital quality is also related to other factors such as the presence of children in the family (Claxton \& Perry-Jenkins, 2008; Lawrence, Rothman, Cobb., Rothman, \& Bradbury, 2008; Hirschberger, Srivastava, Marsh, Cowan, \& Cowan, 2009; Ahlborg, 2009 Misvaer, \& Moller, 2009), personality (Holland \& Roisman, 2008; O'Rourke, Claxton, Chou, Smith, \& Hadjistravropoulus, 2010; Renshaw, Blais, \& Smith, Claxton, O'Rourke, Smith, \& DeLongis, 2012 ; Najarpourian et al., 2012), relationship maintenance behaviors (Badr \& Taylor, 2010; Malinen, Tolvanen, \& Ronka, 2012), and religiosity (Atkins \& Kessel, 2008; Wolfinger \& Wilcox, 2008; Lichter \& Carmalt, 2009; Ellison, Burdette, \& Wilcox, 2010; Whisman, Gordon, \& Chatav, 2011). 
The interest of researchers to examine marital quality has been going on for a long time. At least this can be seen from articles published in journals. For example, Hicks \& Platt (1970) had reviewed studies on marital happiness and marital stability conducted by researchers during the 1960s. Since then research on marital quality has continued. However, Glenn (1990) mentioned that there was no theoretical progress in marital studies in the 1980s. The conceptual development occurred in the next decade, namely the 1990s, as noted by Bradbury, Fincham, \& Beach (2000).

Although marital quality research has been conducted for a long time with a wide range of variables, it is still considered not satisfactory enough from conceptual perspective. Some researchers (Fowers \& Owenz, 2010; Knapp \& Lott, 2010; Fincham \& Rogge, 2010; Knapp \& Holman, 2010) mentioned that marital quality is explained in varying ways, leading to confusion of the concept. This paper will explore the concept of marital quality.

\section{Discussion}

\section{Marital Quality Conceptualization}

Conceptually, there are many terms used to define marital quality. Some of the following terms are commonly used are marital happiness, marital satisfaction, marital stability, marital success, marital adjustment, friendship, and several other terminologies that describe relationship quality (Dush, Taylor, \& Kroeger, 2008; Baxter, 2010; Fincham \& Rogge, 2010; Knapp \& Lott, 2010; Graham, Diebels, \& Barnow, 2011; Li \& Fung, 2011) and are often exchanged to describe marital quality (Fincham \& Rogge, 2010). Looking at these variations, it appears that marital quality is an umbrella term, so it has diverse interpretations (Johnson, White, Edwards, \& Booth, 1986).

Upon further examination at some of the terms above, it appears that there are differences in meaning. For example, marital satisfaction refers to a global subjective evaluation of a person on the quality of one's marriage (Li \& Fung, 2011; Graham et al., 2011). Meanwhile marital happiness is defined as the level of happiness felt by a married couple in their marriage (Dush et al., 2008; Corra, Carter, Carter, \& Knox, 2009). Meanwhile, marital adjustment refers to the characteristics of marital relations, whereas husband and wife agree on important issues, communicate effectively with each other, carry out activities together, have minimal conflict and resolve it the moment conflict arises, and feel satisfied with their marriage (Boden, Fischer, \& Niehuis, 2010). Separation or divorce is usually an indicator of the marital tie continuity and associated with the success or stability of a marriage bond (Fowers, Montels, \& Olson, 1996; Bryant, Conger, \& Meehan, 2001; Brown, Orbuch, \& Bauermeister, 2008; Glenn, Uecker, \& Love Jr., 2010).

The term overlapping often appears in the discussion of marital quality. For example, satisfaction in marriage can be an indicator of marital adjustment (Boden, et al. 2010), whereas marital satisfaction is a specific terminology that is often referred to describe marital quality. Meanwhile, marital happiness and marital satisfaction are stand-alone terms for measuring marital quality. On different occasions, though, the two terms are often used to describe one another. For example, according to Fincham, Ajayi, and Beach (2011), marital satisfaction is measured using a person's global evaluative assessment of marital relationships, including the level of marital happiness. In 
other words, marital happiness is an indicator of marital satisfaction (Kohn, Rholes, Simpson, Martin, Tran, \& Wilson, 2012). The impression of concept overlapping between marital satisfaction and marital happiness was also seen in several other studies (Lorenz, Hraba, \& Pechacova, 2001; Kurdek 2005; Ottu \& Akpan, 2011; Leggett, Roberts-Pittman, Byczek, \& Morse, 2012). It makes the effort to find an established definition of marital quality difficult.

Some experts acknowledged the inadequate conceptualization of marital quality. According to Fowers \& Owenz (2010), studies on marital quality are quite abundant, but the conceptualizations are simple and most are atheoretical. Most researchers explained marital quality only based on husbands and wives' reports about their emotional satisfactions. This opinion is in line with the statement of Fincham \& Rogge (2010) which considered the inadequacy of the conceptualization and operationalization of marital quality, and a similar trend also occurred in studies conducted in China (Zhang, et al., 2012).

Although considered inadequate, there are at least two definitions referenced in various studies on marital quality. Spanier \& Lewis (1980) defined marital quality as a subjective evaluation of the relationship between married couples on a number of dimensions and evaluations. Similar to this definition, Fincham \& Bradbury (1987) stated that marital quality is the couple's feelings which are reflected in subjective and evaluative judgments of the marriage or their partners. The two definitions have one thing in common: the presence of subjective evaluation from the married couple (husband or wife) about their married life. If examined further, subjec- tive evaluation related more to the measurements made through the process of subjective evaluation upon one's marriage.

Similar to the previous opinion, Fowers \& Owenz (2010) defined marital quality as individual's subjective evaluation regarding the condition of the marriage with the purpose of marriage as evaluation criteria. Wahyuningsih (2012) who conducted research in Yogyakarta referred to the opinion of Fowers \& Owenz (2010) to explain marital quality. The difference between the definition of marital quality according to Fowers \& Owenz and the two previous opinions is the evaluation criteria. Thus it can be said that the evaluation criteria for marital quality become the differentiating aspect between one concept and another.

The description shows that there is no definition of marital quality that is widely accepted by experts. The varied notions of marital quality also make it difficult to conclude marital quality conceptually. Therefore, to further clarify the concept of marital quality, meaning of the word quality according to dictionary should be examined. Jaccard and Jacoby (2010) stated that dictionaries are useful in clarifying an abstract concept, so that one of the strategies for establishing a conceptual definition is to refer to the dictionary. According to the Kamus Besar Bahasa Indonesia or KBBI (Departemen Pendidikan Nasional, 2012), quality means "the degree of goodness or badness of something." Quality indicates a degree or level. Good quality means having high level of goodness. Meanwhile in the Merriam-Webster Dictionary, quality can also mean "degree of excellence" or "superiority in kind". Quality shows the attributes or characteristics that distinguish one from another. In line with 
that the Oxford Dictionary describes quality as "the degree of excellence of something" or "a distinctive attribute or characteristic possessed by someone or something". Based on the meaning of quality according to the dictionary, the notion of marital quality is the level of marriage excellence based on certain characteristics.

Certain characteristics or criteria can differ from one region to another. Excellence shows good qualities, and according to Fowers (2012) goodness is shaped by culture, and culture can vary according to the values or norms that develop in each region. Goodness is also an open concept, because humans are intelligent beings. This would make the concept of marital quality vary.

The criteria for marital superiority can also change from time to time. Some studies showed that cultural shifts affect how people perceive good marriages. For example, industrialization and modernization in Taiwan have led to changes in husband and wife's relations (Shen, 2005). According to Parris \& Farrer (in Zhang et al., 2012; Zhang, 2015), the shift in the economic role of urban Chinese women has also significantly affected marital relations qualitatively.

In Indonesia, both political policy and cultural change shift the way society views the position of women in the family. The democratization and gender equality movement initiated by a number of nongovernmental organizations in Indonesia (Brenner, 2011) as well as the state through gender mainstreaming policies in national development (Presidential Instruction No. 9 of 2000) changed the public's view about the relations of men and women, including marriage. Likewise, the values developed in society regarding working women have encouraged an increase of women's participation in the working force. It can be seen from the participation of Indonesian women in workforce in 1980 at $32.43 \%$, in 1990 at $38.79 \%$, and in 2014 it increased to $50.22 \%$ (Rahayu, 2015).

In addition, current advances in information technology have caused significant changes in nearly everyone's life which add meaning to life. The way of life that was based on natural patterns of relationships is now done in novel ways, which means relying on technology. Through that mode, interconnection and interdependence between humans can occur virtually (Piliang, 2012). Relationship between husband and wife cannot avoid these social changes. Advances in information technology provide opportunities for married couples to experience relationships in novel ways.

Changes due to cultural shifts and advances in information technology as described above allow for a shift in the way people think about "a good marriage". Therefore, the formulation of the concept of marital quality can also change in line with changes in society.

\section{Marital Quality Dimensions}

The terms dimensions and aspects are often exchanged, though they are in fact different. The main difference between the two is related to testing. Aspects are areas of the measuring domains which have not been tested to determine whether each has independence or not. If each of these theoretical domains is independent, as proven by factor analysis, then it is called a dimension or factor (Widhiarso, 2010). Although different, both explain the domains of measurement which means the translation of a construct. Therefore, discussion about dimensions in this context also includes dimensions and aspects of marital quality. 
The dimension of marital quality is one of the debates that attracts experts' interests. The debate covers whether marital quality is a single or multidimensional concept. Some experts considered that marital quality is a single dimension concept (Norton, 1983; Fletcher, Simpson \& Thomas, 2000). Meanwhile Allendorf \& Ghimire (2012) denied this by stating there was a broad agreement that marital quality is a multidimensional concept.

Research conducted by several experts proved that marital quality is a multidimensional concept (Johnson et al., 1986; Haussebrauck \& Fehr, 2002; Verhofstadt, Buysse, Rosseel, \& Peene; 2006; Allendorf \& Ghimire, 2012; Zhang et al., 2012 ). Each of these researchers identified different dimensions.

Johnson et al., (1986) conducted a factor analysis and identified a twodimensional structure of marital quality. Both dimensions were positive dimensions which included marital happiness and marital interaction, and negative dimensions that consisted of disagreement, marital problems, and marital instability. Marriage happiness refers to the level of satisfaction or happiness felt by a person towards one's marriage, while marital interaction is the extent of husband and wife interaction. Disagreement reflects the lack of consensus between husband and wife regarding individual goals and marital goals or other problems inside and outside of the marriage. Marriage problems indicate the degree of traits or behaviors of husband and or wife that might cause problems in marriage. Meanwhile marital instability refers to tendency to divorce, which is comprised of cognitive and behavioral components. Zhang, et al. (2012) developed and validated the scale of marital quality using the construct identified in study by
Johnson et al.. Factor analysis conducted by Zhang et al. confirmed the existence of five domains which were then grouped into positive and negative dimensions.

Meanwhile Haussebrauck \& Fehr (2002) identified and confirmed four dimensions of relationship quality: intimacy, agreement, independence, and sexuality. In the study Haussebrauck \& Fehr also found that intimacy has a central role in a relationship. Intimacy is comprised of spending time together, listening to each other, being open, honest, and trusting each other. Agreement means similarity, suitability, and common goals in married couple. Independence refers to autonomy, individuality and freedom. Meanwhile, sexuality is a factor related to physical contact and sexual satisfaction.

Lawrence, et al. (2011) developed a measurement of the quality of close relationships in interview format. This measurement includes five dimensions of relationship quality, namely 1) intimacy which includes trust and a sense of closeness, warmth, affection, and interdependence with each other; 2 ) the quality of sexual relation. This includes the frequency of sexual intercourses, emotions during and after sexual intercourses, the frequency and quality of sexual activities, and issues in sexual intercourses; 3) support, which is related to mutual support behavior when the couple is experiencing a bad day, facing a problem, or feeling down; 4) power, is the ability of couples to share power in relationships; and 5) conflict, which includes conflict and conflict management in relationships.

Other researchers who seek to analyze dimensions of marital quality were Allendorf \& Ghimire (2012). They conducted exploratory factor analysis and identified five factors of marital quality, namely: satisfaction, communication, 
togetherness, problems, and disagreements. Satisfaction includes one's satisfaction and happiness about his/her marriage. Communication refers to the frequency of married couples being involved in discussion about various topics. Meanwhile togetherness refers to activities spent together as husband and wife. Two other negative factors point out a person's perception of whether there is a problem in one's marriage and how much one disagrees with his/her partner.

Meanwhile Wahyuningsih (2012) in her research in Yogyakarta identified three dimensions of marital quality, namely: friendship, harmony, and satisfaction abour children. Friendship is the level of agreement and activity together as husband and wife. Harmony means a sense of calmness and minimal conflict. Meanwhile, satisfaction about children illustrates a person's level of satisfaction with the child's success and behavior.

In addition to some of the studies above, there are other studies that showed measures of marital quality. Dyadic Adjustment Scale (DAS) is one of the most widely used marital quality measurement tools (Graham, Liu, \& Jeziorski, 2006). Dyadic Adjustment Scale was developed by Spanier (1976) to measure husband and wife's adjustments which includes four factors namely: 1) dyadic satisfaction, which measures husband and wife's satisfaction, 2) dyadic cohesion, which describes the level of closeness and activity with husband and wife, 3) dyadic consensus, which shows the level of agreement between husband and wife related to important issues in relationships, and 4) dyadic expression, which refers to expression of affection and sexual relations.

Based on the description above, it appears that the researchers proposed dimensions of marital quality that are different from each other. Zhang, et al. (2012) referred to the research of Johnson, et al. (1986) so that there were common identified dimensions. Although different from each other, there is a conceptual proximity among those dimensions. As an example, the similarity between intimacy, togetherness, and harmony. Sexuality can also be included in the concept of intimacy. Another example is disagreement, which is the opposite or negative dimension of the agreement. Overall, it appears that the dimensions of marital quality refer to qualities that are positive as well as those that are negative. Positive dimensions include qualities such as happiness, satisfaction, intimacy, consensus, agreement, independence, harmony, and sexuality. Meanwhile the negative dimensions are related to conflicts, problems, or disagreements. The dimensions of marital quality can also be categorized into intrapersonal dimensions such as satisfaction and happiness, and interpersonal dimensions as seen in intimacy, consensus, agreement, sexuality, harmony, conflict, and disagreements.

\section{Factors Affecting Marital Quality}

A review of the factors that influence marital quality is carried out by looking at the determinant factors used in studies of marital quality. These factors will be explained in the following description.

Transition in marriage and presence of children. The transition in marriage as a factor influencing marital quality has actually become a concern of researchers for a long time (Glenn, 1990; Gottman \& Notarius, 2000). The results of research over the past ten years reinforced the previous results that transition to parenthood because of the presence of a child affects couples' marital quality. 
There is a tendency of decreased marital satisfaction as time goes by and during the transition to parenthood, and in the presence of children in family (Claxton \& Perry-Jenkins, 2008; Hirschberger et al., 2009; Ahlborg, et al. 2009). However, the decline in marital quality is likely to only occur in couple's sexual life, not in marital life in general (Ahlborg, Persson \& Hallberg, 2005). Sexual relationship may be difficult when the children are young. They often share a bed or room with their children so that it takes away the intimacy the couple needs (Duvall, 1977). The emergence of conflict during the transition period is also suspected to be a cause of deterioration in the quality of marital relations. The higher the frequency of conflict during pregnancy is related to the lower quality of relationship during transition to parenthood (Kluwer \& Johnson, 2007).

Personality. Several studies had shown that the couple's personality affects marital quality. Neuroticism, extraversion, agreeableness, conscientiousness, and positive expression are related to marital quality (Renshaw, Blais, \& Smith, 2010; Claxton, O'Rourke, Smith, \& DeLongis, 2012; Najarpourian, et al., 2012). For example Gattis, Berns, Simpsom, \& Christensen's (2004) research found that high neuroticism, low agreeableness, low conscientiousness, and lack of positive expression related to marital dissatisfaction. In regards to personality, attachment style gets special attention from researchers. Initially, attachment is described as a bond between a caregiver (usually a mother) and a child, but later it is also used in the context of romantic relationships (Hollist \& Miller, 2005). Affective attachment or relationship between two people, in this case is husband and wife, was found to be related to marital quality (Knoke, Burau, \&
Roehrle, 2010; Sheftall, Schoppe-Sullivan, \& Futris, 2010; Ottu \& Akpan, 2011; Lopez, Riggs, 2010 Pollard, \& Hook, 2011; Tan, Overall, \& Taylor, 2011; Kohn, et al., 2012). The satisfaction of a marital relationship can be predicted from one's attachment style, the couple's attachment style, as well as combination of both (Banse, 2004). For example, Knoke, Burau, \& Roehrle (2010) found that anxious attachment cause a decrease in marital quality.

Religiosity and Spirituality. The correlation between religiosity and spirituality, both in the form of beliefs and in the presence of religious activities with marital quality has been widely studied for a long time (Mahoney et al., 1999). However, research on the correlation between religiosity and marital quality continues today. In line with previous studies reviewed by Mahoney et al., (1999), religiosity is positively related to marital adjustment (Lopez et al., 2011; Schramm, Marshall, Harris, \& Lee, 2012). Religiosity and attendance at services are also directly or indirectly related to marital quality, lower chance of infidelity, domestic violence, and divorce (Atkins \& Kessel, 2008; Lichter \& Carmalt, 2009; Ellison et al., 2010; Whisman et al., 2011).

Gender Role Attitude. Several studies had shown the influence of gender role attitude in marital quality. Gender role attitude refers to ideas about the characteristics, behaviors and activities of men and women, including in terms of work and household roles. Individuals with conservative attitudes support the division of labor that separates men and work outside of home from women and household work for no pay. Meanwhile, egalitarian attitudes support the role equality of men and women (McHugh \& Frieze, 1997). Marital quality is positively influenced by the egalitarian gender views 
of the husband and wife (Rhoden, 2003; Xu \& Lai, 2004; Kaufman \& Taniguchi, 2006; Stanick \& Bryant, 2012). Egalitarian attitudes and nontraditional work division are positively related to flexibility, harmony and negatively related to marital disagreements (Rhoden, 2003; Xu \& Lai, 2004). Husbands who have egalitarian attitudes have significantly higher levels of marital happiness than those who have conservative attitudes (Kaufman \& Taniguchi, 2006).

Coping Strategy. Every marriage has problems, and how a married couple solves the problem contributes to marital quality. Couples who experience greater stress show a decrease in marital happiness. However, the experience of solving moderate problems can increase resilience in the face of subsequent stressors and have an effect on marital adjustment (Neff \& Broady, 2011). Dyadic coping or how a married couple deals with individual or shared stressors is also related to marital quality. Marital quality is higher in couples who communicate the stress that they experience more often, use more positive dyadic coping, less negative dyadic coping, and in particular, show higher tendency of common dyadic coping. Common dyadic coping shows the harmony between husband and wife in overcoming problems (Wunderer \& Schneewind, 2008; Badr, Carmack, Kashy, Cristofanilli, \& Revenson, 2010; Bodenmann, Meuwly, \& Kayser, 2011).

Communication. Communication in marriage has long been found as a factor influencing marital quality (Fowers, 1998). There is a correlation between positive and negative communication behaviors with marital quality in married couples (Rehman \& Holzworth-Munroe, 2007; Ledermann, Bodenmann, Rdaz, \& Bradbury, 2011). In the context of parenting, couples who have good parenting communication show higher satisfaction with their marital relationship (Schrodt \& Braithwaite, 2011). Parenting communication through the expression of positive emotions, especially from husband can prevent negative parenting interactions when facing unfavorable conditions (Kolak \& Volling, 2007; Solomon, Debby-Aharon, Zerah, \& Horesh, 2010). The feeling of being understood through communication is also important in maintaining marital quality. Husband or wife will feel less understood by their partner if their partner withdraws from conflict, even though the feeling of being understood is positively correlated with marital satisfaction (Weger, 2005). This is also reinforced by Moorman's study (2011) in elderly married couples who showed that those who reported high quality marriages felt very well understood by their partners.

Relationship maintenance behaviour. Relationship maintenance behavior is everyday behavior that keeps a relationship running in satisfying state. Such behavior was proven to be related to marital quality (Badr \& Taylor, 2010; Malinen et al., 2012). Relationship maintenance behavior includes positivity, openness, assurance, networks, and tasks. Positivity is the interaction of couples in a way that is fun, optimistic, and not critical. Openness refers to the act of discussing the nature of a relationship directly and expressing one's desire for that relationship. Assurance includes words that emphasize the sustainability of relationships. Network utilization is interaction or trust in certain relatives or affiliations. Meanwhile, tasks refer to efforts to maintain relationships by showing one's responsibilities, such as in the daily household tasks (Canary \& Stafford, 1992). 
Beyond these forms of behaviors, gratitude also plays a role in maintaining an intimate relationship (Kubacka, Finkenauer, Rusbult, \& Keijsers, 2011; Gordon, Impett, Kogan, Oveis, \& Keltner, 2012).

Economy and finance. Socioeconomic status, especially issues related to economy and finance, are of concern to researchers in marital quality. Several studies have shown relationships between economic and financial problems with marital quality (Kinnunen \& Feldt, 2004; Papp, Cummings, \& Goeke-Morey, 2009; Hardie \& Lucas, 2010). Moreover, disagreements and financial dissatisfaction are strong predictors of divorce (Poortman, 2005; Grable, Britt, Cantrell, 2007), even stronger than disagreements in other matters such as division of duty or time spent together (Dew, Britt, \& Huston, 2012). However, perception of financial problems was found to be related to materialistic attitude of the couple and this affected marital satisfaction both directly and indirectly. The higher the level of materialism in married couples, their perceptions of financial problems also increase and negatively correlated to marital satisfaction (Dean, Caroll \& Yang, 2007). Meanwhile, how couples plan household finances is also related to marital quality. Couples who implement independent financial planning show lower levels of marital satisfaction than those who work together with their partners in financial planning (Addo \& Sassler, 2010).

Based on the description above, it can be concluded that the factors that influence marital quality are intrapersonal factors, such as personality, religiosity, and attitude toward gender role and interpersonal factors, such as communication and the economic condition of a household.

\section{Conclusion}

The concept of marital quality varies greatly, because marital quality is related to marital superiority. Meanwhile the criteria for marital superiority can differ from one region to another and may change from time to time. Therefore concept formulation of marital quality can be different and shift according to changes that occur in society. In line with the concept, the dimensions of marital quality also vary according to the concept used by experts. The construct of marital quality can be unidimensional or multidimensional. Marriage quality dimensions can also be distinguished into intrapersonal dimensions such as satisfaction and happiness, and interpersonal dimensions as seen in intimacy, consensus, agreement, sexuality, harmony, conflict, and disagreements. As its dimensions, factors that influence marital quality can be grouped into intrapersonal factors such as personality, religiosity, and gender and interpersonal factors such as communication and the economic status of a household. Based on the literature review and conclusions obtained, there are still opportunities for researchers to develop the concept of marital quality that is in accordance to the local context.

\section{References}

Addo, F. R., \& Sassler, S. (2010). Financial arrangements and relationship quality in low-income couples. Family Relations, 59, 408-423. doi: 10.1111/ j.1741-3729.2010.00612.x

Ahlborg, T., Misvaer, N., \& Möller, A. (2009). Perception of marital quality by parents with small children: A followup study when the firstborn is 4 years old. Journal of Family Nursing, 15(2), 
237-263. doi: $\quad \underline{10.1177 / 107484}$ $\underline{0709334925}$

Ahlborg, T., Persson, L., \& Hallberg, L. R. M. (2005). Assessing the quality of the dyadic relationship in first-time parents: Development of a new instrument. Journal of Family Nursing, 11(1), 19-37. doi: $\underline{10.1177 /}$ $\underline{1074840704273462}$

Allendorf, K., \& Ghimire, D. J. (2012). Determinants of marital quality in an arranged marriage society. Social Science Research, 42, 59-70. doi: 10.1016/j.ssresearch.2012.09.002

Atkins, D. C. \& Kessel, D. E. (2008). Religiousness and infidelity: Attendance, but not faith and prayer, predict marital fidelity. Journal of Marriage and Family, 70(2), 407-418.

Badr, H., \& Taylor, C. L. C. (2010). Effects of relationship maintenance on psychological distress and dyadic adjustment among couples coping with lung cancer. Health Psychology, 27(5), 616-627. doi: 10.1037/0278$\underline{6133.27 .5 .616}$

Badr, H., Carmack, C. L., Kashy, D. A., Cristofanilli, M., \& Revenson, T. A. (2010). Dyadic coping in metastatic breast cancer. Health Psychology, 29(2), 169-180. doi: $10.1037 / \mathrm{a} 0018165$

Banse, R. (2004). Adult attachment and marital satisfaction: Evidence for dyadic configuration effects. Journal of Social and Personal Relationships, 21(2), 273-282. doi: $\underline{10.1177 / 02654075040}$ $\underline{41388}$

Baxter, L. A. (2010). The dialogue of marriage. Journal of Family Theory and Review, 2, 370-387.

Boden, J. S., Fischer, J. L., \& Niehuis, S. (2010). Predicting marital adjustment from young adults' initial levels and changes in emotional intimacy over time: A 25-year longitudinal study. Journal of Adult Development, 17, 121134

Bodenmann, G., Meuwly, M., \& Kayser, K. (2011). Two conceptualizations of dyadic coping and their potential for predicting relationship quality and individual well-being. European Psychologist, 16(4), 255-266

Bookwala, J. (2005). The role of marital quality in physical health during the mature years. Journal of Aging and Health, 17(1), 85-104. doi: 10.1177/0898264304272794

Bradbury, T. N., Fincham, F. D., \& Beach, S. R. (2000). Research on the nature and determinants of marital satisfaction: A decade in review. Journal of Marriage and Family, 62(4), 964-980.

Brenner, S. (2011). Privat moralities in the public sphere: Democratization, Islam, and gender in Indonesia. American Anthropologist, 113(3), 478-490. doi: 10.1111/j.1548-1433.2010.01355.x

Brown, E., Orbuch, T. L., \& Bauermeister, J. A. (2008). Religiosity and marital stability among Black American and White American couples. Family Relations, 57(2), 186-197.

Bryant, C. M., Conger, R. D., \& Meehan, J. M. (2001). The influence of in-laws on change in marital success. Journal of Marriage and Family, 63, 614-626

Canary, D. J., \& Stafford, L. (1992). Relational maintenance strategies and equity in marriage. Communication Monographs, 59, 243-267. doi: $\underline{10.1080 / 03637759209376268}$

Claxton, A., \& Perry-Jenkins, M. (2008). No fun anymore: Leisure and marital quality across the transition to parenthood. Journal of Marriage and Family, 70, 28-43 
Claxton, A., O'Rourke, N., JuliAnna Z. Smith, J.A., \& DeLongis, A. (2012). Personality traits and marital satisfaction within enduring relationships: An intra-couple discrepancy approach. Journal of Social and Personal Relationships, 29(3), 375-396. doi: $\underline{10.1177 / 0265407511431183}$

Corra, M. Carter, S.K., Carter, J.S., \& Knox, D. (2009). Trends in marital happiness by gender and race, 1973 to 2006. Journal of Family Issues, 30(10), 13791404. doi: $10.1177 / 0192513 X 09336214$

Dean, L. R., Caoll, J. S., \& Yang, C. (2007). Materialism, perceived financial problems, and marital satisfaction. Family and Consumer Sciences Research Journal, 35(3), 260-281. doi: 10.1177/ $\underline{1077727 X 06296625}$

Departemen Pendidikan Nasional (2012). Kamus Besar Bahasa Indonesia. Jakarta: PT Gramedia Pustaka Utama

Dew, J., Britt, S., \& Huston, S. (2012). Examining the relationship between financial issues and divorce. Family Relations, 61, 615-628. doi: 10.1111/ j.1741-3729.2012.00715.x

Dush, C. M. K., Taylor, M. G., \& Kroeger, M. A. (2008). Marital happiness and psychological well-being across the life course. Family Relations, 57, 211-226

Duvall, E. M. (1977). Marriage and family development. New York: J.B. Lippincott Company

Ellison, C. G., Burdette, A. M., \& Wilcox, W. B. (2010). The couple that prays together: Race and ethnicity, religion, and relationship quality among working-age adults. Journal of Marriage and Family, 72, 963-975. doi: 10.1111/j.1741-3737.2010.00742.x

Fincham, F. D. \& Linfield, K. J. (1997). A new look at marital quality: Can spouses feel positive and negative about their marriage?. Journal of Family Psychology, 11(4), 489-502

Fincham, F. D., \& Rogge, R. (2010). Understanding relationship quality: Theoretical challenges and new tools for assesment. Journal of Family Theory $\mathcal{E}$ Review, 2, 227-242. doi: 10.1111/ j.1756-2589.2010.00059.x

Fincham, F. D., Ajayi, C., \& Beach, S. R. H. (2011). Spirituality and marital satisfaction in African American couples. Psychology of Religion and Spirituality, 3(4), 259-268. doi: $\underline{10.1037 / a 0023909}$

Fletcher, G. J. O., Simpson, J. A., \& Thomas, G. (2000). The measurement of perceived relationship quality components: A confirmatory factor analytic approach. Personality and Social Psychology Bulletin, 26(3), 340354. doi: $10.1177 / 0146167200265007$

Fowers, B. J. \& Owenz, M. B. (2010). A eudaimonic theory of marital quality. Journal of Family Theory and Review. 2, 334-352. doi: 10.1111/j.1756-2589.2010. $\underline{00065 . x}$

Fowers, B.J. (1998). Psychology and the good marriage: Social theory as practice. American Behavioral Scientist, 41(4), 516-541. doi: $\underline{10.1177 /}$ $\underline{0002764298041004005}$

Fowers, B. J., Montel, K. H., \& Olson, D. H. (1996). Predicting marital success for premarital couple types based on prepare. Journal of Marital and Family Therapy, 22(1), 103-119

Frech, A., \& Williams, K. (2007). Depression and the psychological benefits of entering marriage. Journal of Health and Social Behavior, 48(2), 149163. doi: $10.1177 / 002214650704800204$

Gattis, K. S., Berns, S., Simpson, L. E., \& Christensen, A. (2004). Birds of a feather or strange birds? Ties among 
personality dimensions, similarity, and marital quality. Journal of Family Psychology, 18(4), 564-574. doi: 10.1037/0893-3200.18.4.564

Glenn, N. D., Uecker, J. E., \& Love, R. W. (2010). Later first marriage and marital success. Social Science Research, 39(5), 787-800.

Glenn, N. D. (1990). Quantitative research on marital quality in the 1980s: A critical review. Journal of Marriage and Family, 52(4), 818-831

Gordon, A. M., Impett, E. A., Kogan, A., Oveis, C., \& Keltner, D. (2012). To have and to hold: Gratitude promotes relationship maintenance in intimate bonds. Journal of Personality and Social Psychology, 103(2), 257-274. doi: $\underline{10.1037 / \mathrm{a} 0028723}$

Gottman, J. M., \& Notarius, C. I. (2000). Decade review: Observing marital interaction. Journal of Marriage and Family, 62(4), 927-947.

Grable, J. E., Britt, S., \& Cantrell, J. (2007). An exploratory study of the role financial satisfaction has on the thought of subsequent divorce. Family and Consumer Sciences Research Journal, 36(2), 130-150. doi: $\underline{10.1177 /}$ $\underline{1077727 \times 07309284}$

Graham, J. M., Diebels, K. J., \& Barnow, Z. B. (2011). The reliability of relationship satisfaction: A reliability generalization meta-analysis. Journal of Family Psychology, 25(1), 39-48. doi: $\underline{10.1037 / \mathrm{a} 0022441}$

Graham, J. M., Liu, Y. J., \& Jeziorski, J. L. (2006). The dyadic adjustment scale: A reliability generalization meta-analysis. Journal of Marriage and Family, 68, 701717.

Hardie, J. H., \& Lucas, A. (2010). Economic factors and relationship quality among young couples: Comparing cohabita- tion and marriage. Journal of Marriage and Family, 72, 1141-1154. doi: 10.1111/j.1741-3737.2010.00755.x

Haussebrauck, M., \& Fehr, B. (2002). Dimensions of relationship quality. Personal Relationships, 9, 253-270

Hicks, M. W. \& Platt, M. (1970). Marital happiness and stability: A review of the research in the sixties. Journal of Marriage and Family, 32(4), 553-574

Hirschberger, G., Srivastava, S., Marsh, P., Cowan C. P., \& Cowan, P. A. (2009). Attachment, marital satisfaction, and divorce during the first fifteen years of parenthood. Personal Relationships, 16, 401-420.

Holland, A. S., \& Roisman, G. I. (2008). Big five personality traits and relationship quality: Self-reported, observational, and physiological evidence. Journal of Social and Personal Relationships, 25(5), 811-829. doi: $10.1177 / 026540750$ $\underline{8096697}$

Hollist, C. S., \& Miller, R. B. (2005). Perceptions of attachment style and marital quality in midlife marriage. Family Relations, 54, 46-57

Holt-Lunstad, J., Birmingham, W., \& Jones, B. Q. (2008). Is there something unique about marriage? The relative impact of marital status, relationship quality, and etworkn social support on ambulatory blood pressure and mental health. Annals of Behavior Medicine, 35, 239-244. doi: 10.1007/s12160-0089018-y

Jaccard, J., \& Jacoby, J. (2010). Theory construction and model-building skills. A practical guide for social scientists. New York: The Guilford Press

Johnson, D. R., White, L. K., Edwards, J. N., \& Booth, A. (1986). Dimensions of marital quality: Toward methodolo- 
gical and conceptual refinement. Journal of Family Issues, 7(1), 31-49.

Kaufman, G. \& Taniguchi, H. (2006). Gender and marital happiness in later life. Journal of Family Issues, 27(6), 735757. doi: $\underline{10.1177 / 0192513 X 05285293}$

Kim, E. (2012). Marital adjustment and depressive symptoms in Korean Americans. Issues in Mental Health Nursing, 33, 370-376. doi: 10.3109/ $\underline{01612840.2012 .656822}$

Kim, H. K., \& McKenry, P. C. (2002). The relationship between marriage and psychological well-being: A longitudinal analysis. Journal of Family Issues, 23(8), 885-911. doi: $\underline{10.1177 /}$ $\underline{019251302237296}$

Kinnunen, U., \& Feldt, T. (2004). Economic stress and marital adjustment among couples: Analyses at the dyadic level. European Journal of Social Psychology, 34, 519-532. doi: $10.1002 /$ ejsp.213

Kluwer, E. S., \& Johnson, M. D. (2007). Conflict frequency and relationship quality across the transition to parenthood. Journal of Marriage and Family, 69, 1089-1106

Knapp, S. J. \& Lott, B. (2010). Forming the central framework for a science of marital quality: an interpretive alternative to marital satisfaction as a proxy for marital quality. Journal of Family Theory \& Review, 2, 316-333. doi: 10.1111/j.1756-2589.2010.00064.x

Knapp, S. J., \& Holman, T. B. (2010). Introducing a special issue: On the need to theorize marital quality. Journal of Family Theory \& Review, 2, 221-226. doi: 10.1111/j.17562589.2010.00058.x

Knoke, J., Burau, J., \& Roehrle., B. (2010). Attachment styles, loneliness, quality, and stability of marital relationships. Journal of Divorce \& Remarriage, 51,
310-325. doi: 10.1080/1050255100 $\underline{3652017}$

Kohn, J. L., Rholes, S. W., Simpson, J. A., Martin III, A. M., Tran, S., \& Wilson, C. L. (2012). Changes in marital satisfaction across the transition to parenthood: The role of adult attachment orientations. Personality and Social Psychology Bulletin, 38(11), 1506-1522. doi: $\underline{10.1177 / 0146167212454548}$

Kolak, A. M., \& Volling, B. L. (2007). Parental expressiveness as a moderator of coparenting and marital relationship quality. Family Relations, $56,467-478$.

Kubacka, K. E., Finkenauer, C., Rusbult, C. E., \& Keijsers, L. (2011). Maintaining close relationships: Gratitude as a motivator and a detector of maintenance behavior. Personality and Social Psychology Bulletin, 37(10), 13621375. doi: $\underline{10.1177 / 0146167211412196}$

Kurdek, L.A. (2005). Gender and marital satisfaction early in marriage: A growth curve approach. Journal of Marriage and Family, 67, 68-84

Lawrence, E., Barry, R. A., Brock, R. L., Bunde, M., Langer, A., Ro, E., Fazio, E., Mulryan, L., Hunt, S., Madsen, L., \& Dzankovic, S. (2011). The relationship quality interview: Evidence of reliability, convergent and divergent validity, and incremental utility. Psychological Review, 23(1), 4463. doi: $\underline{10.1037 / a 0021096}$

Lawrence, E., Rothman, A. D., Cobb., R. J., Rothman, M. T., \& Bradbury, T. N. (2008). Marital satisfaction across the transition to parenthood. Journal of Family Psychology, 22(1), 41-50. doi: $\underline{10.1037 / 0893-3200.22 .1 .41}$

Ledermann, T., Bodenmann, G., Rdaz, M., \& Bradbury, T. N. (2011). Stress, communication, and marital quality in 
couples. Family Relations, 59, 195-206. doi: 10.1111/j.1741-3729.2010.00595.x

Leggett, D. G., Roberts-Pittman, B., Byczek, S., \& Morse, D. T. (2012). Cooperation, conflict, and marital satisfaction: Bridging theory, research, and practice. The Journal of Individual Psychology, 68(2), 182-199.

Li, T., \& Fung, H. H. (2011). The dynamic goal theory of marital satisfaction. Review of General Psychology, 15(3), 246254. doi: $10.1037 / \mathrm{a} 0024694$

Lichter, D. T., \& Carmalt, J. H. (2009). Religion and marital quality among low income couples. Social Science Research, 38, 168-187.

Lopez, J. L., Riggs, S. A., Pollard, S. E., \& Hook, J. N. (2011). Religious commitment, adult attachment, and marital adjustment in newly married couples. Journal of Family Psychology, 25(2), 301-309. doi: 10.1037/a0022943

Lorenz, F. O., Hraba, J., \& Pechacova, Z. (2001). Effects of spouse support and hostility on trajectories of Czech couples' marital satisfaction and instability. Journal of Marriage and Family, 63(4), 1068-1082.

Mahoney, A., Pargament, K. I., Jewell, T., Swank, A. B., Scott, E., Emery, E., \& Rye, M. (1999). Marriage and the spiritual realm: the role of proximal and distal religious constructs in marital functioning. Journal of Family Psychology, 13(3), 321-338.

Malinen, K., Tolvanen, A., \& Ronka, A. (2012). Accentuating the positive, eliminating the negative? Relationship maintenance as a predictor of twodimensional relationship quality. Family Relations, 61, 784-797. doi: 10.1111/j.1741-3729.2012.00738.x

McHugh, M. C., \& Frieze, I. H. (1997). The measurement of genderrole attitudes:
A review and commentary. Psychology of Women Quarterly, 21, 1-16.

Moorman, S. M (2011). The importance of feeling understood in marital conversations about end-of-life health care. Journal of Social and Personal Relationships, 28(1). 100-116. doi: $\underline{10.1177 / 0265407510386137}$

Najarpourian, S., Fatehizadeh, M., Etemadi, O., Ghasemi, V., Abedi, M. R., \& Bahrami, F. (2012). Personality types and marital satisfaction. Interdisciplinary Journal of Contemporary Research in Bussiness, 4(5), 372-382.

Neff, L. A., \& Broady, E. F. (2011). Stress resilience in early marriage: Can practice make perfect? Journal of Personality and Social Psychology, 101(5), 1050-1067. doi: 10.1037/a0023809

Norton, R. (1983). Measuring marital quality: A critical look at the dependent variable. Journal of Marriage and Family, 45(1), 141-151

O'Rourke, N., Claxton, A, Chou, P. H. B., Smith, J. Z., \& Hadjistravropoulus, T. (2010). Personality trait levels within older couples and between-spouse trait differences as predictors of marital satisfaction. Aging and Mental Health, 15(3), 344-353.

Ottu, I. F. A., \& Akpan, U. I. (2011). Predicting marital satisfaction from the attachment styles and gender of a culturally and religiously homogenous population. Gender $\mathcal{E}$ Behaviour, 9(1), 3656-3679

Papp, L. M., Cummings, E. M., \& GoekeMorey, M. C. (2009). For richer, for poorer: Money as a topic of marital conflict in the home. Family Relations, $58,91-103$

Piliang, Y. A. (2012). Masyarakat informasi dan digital: Teknologi informasi dan 
perubahan sosial. Jurnal Sosioteknologi, 27, 143-156.

Poortman, A. (2005). How work affects divorce: The mediating role of financial and time pressures. Journal of Family Issues, 26(2), 168-195. doi: $\underline{10.1177 / 0192513 X 04270228}$

Proulx, C. M., Helms, H. M., \& Buehler, C. (2007). Marital quality and personal well-being: A meta-analysis. Journal of Marriage and Family, 69, 576-593

Rahayu, A.W. (2015). Perempuan dan belenggu peran kultural. Jurnal Perempuan, 29/1/2015, diakses online melalui http://www.jurnalperempuan. org/blog2/perempuan-dan-belengguperan-kultural

Rehman, U. S., \& Holzworth-Munroe, A. (2007). A cross-cultural examination of the relation of marital communication behavior to marital satisfaction. Journal of Family Psychology, 21(4), 759-763. doi: $10.1037 / 0893-3200.21 .4 .759$

Renshaw, K. D., Blais, R. K., \& Smith, T. W. (2010). Components of negative affectivity and marital satisfaction: The importance of actor and partner anger. Journal of Research in Personality, 44, 328-334.

Rhoden, J. L. (2003). Marital cohesion, flexibility, and communication in the marriages of nontraditional and traditional women. The Family Journal, 11(3), 248-256, doi: $\underline{10.1177 /}$ 1066480703251988

Rogers, S. J. \& May, D. C. (2003). Spillover between marital quality and job satisfaction: Long-term patterns and gender differences. Journal of Marriage and Family, 65(2), 482-495

Ryan, A. K., \& Willits, F. K. (2007). Family ties, physical health, and psychological Well-being. Journal of Aging and Health,
19(6), 907-920. doi: $\underline{10.1177 /}$ $\underline{0898264307308340}$

Schramm, D. G., Marshall, J. P., Harris, V. W., \& Lee, T. R. (2012). Religiosity, homogamy, and marital adjustment: An examination of newlyweds in first marriages and remarriages. Journal of Family Issues, 33(2), 246-268. doi: $\underline{10.1177 / 0192513 X 11420370}$

Schrodt, P., \& Braithwaite, D. O. (2011). Coparental communication, relational satisfaction, and mental health in stepfamilies. Personal Relationships, 18, 352-369. doi: 10.1111/j.14756811.2010.01295.x

Sheftall, A. H., Schoppe-Sullivan, S. J., \& Futris, T. G. (2010). Adolescent mothers' perceptions of the coparenting relationship with their child's father: A function of attachment security and trust. Journal of Family Issues, 31(7), 884-905. doi: 10.1177/0192513X09359892

Shen, A. C. (2005). Factors in the marital relationship in a changing sociality. International Social Work, 48(3), 325-340. doi: $\underline{10.1177 / 0020872805051735}$

Solomon, Z., Debby-Aharon, S., Zerah, G., \& Horesh, D. (2010). Marital adjustment, parental functioning, and emotional sharing in war veterans. Journal of Family Issues, 32(1), 127-147. doi: $\underline{10.1177 / 0192513 \times 10379203}$

Spanier, G. B. (1976). Measuring dyadic adjustment: New scales for assessing the quality of marriage and similar dyads. Journal of Marriage and the Family, 38(1), 15-28.

Spanier, G. B. \& Lewis, R. A. (1980). Marital quality: A review of the seventies. Journal of Marriage and Family, 42(4), 825-839

Stanick, C. E., \& Bryant, C. M. (2012). Marital quality of newlywed African 
American couples: Implications of egalitarian gender role dynamics. Sex Roles, 66, 256-267. doi: 10.1007/s11199012-0117-7

Tan, R., Overall, N. C., \& Taylor, J. K. (2011). Let's talk about us: Attachment, relationship-focused disclosure, and relationship quality. Personal Relationships, 1-14, doi: 10.1111/j.14756811.2011.01383.x

Troxel, W. M., Robles, T. F., Hall, M., \& Buysse, D. J. (2007). Marital quality and the marital bed: Examining the covariation between relationship quality and sleep. Sleep Medicine Reviews, 11, 389-404. doi: 10.1016/j.smrv.2007.05.002

Umberson, D., Williams, K., Powers, D. A., Liu, H., Needham, B. (2006). You make me sick: Marital quality and health over the life course. Journal of Health and Social Behavior, 47, 1-16. doi: $\underline{10.1177 / 002214650604700101}$

Verhofstadt, L. L., Buysse, A., Rosseel, Y., \& Peene, O. J. (2006). Confirming the three-factor structure of the quality of relationships inventory within couples. Psychological Assesment, 18(1), 15-21. doi: $10.1037 / 1040-3590.18 .1 .15$

Wahyuningsih, H. (2012). Model psikologis kualitas perkawinan pasangan suami isteri. Disertasi(tidak dipublikasikan). Yogyakarta: Fakultas Psikologi UGM.

Weger, H. (2005). Disconfirming communication and self-verification in marriage: Associations among the demand/withdraw interaction pattern, feeling understood, and marital satisfaction. Journal of Social and Personal Relationships, 22(1), 19-31. doi: $\underline{10.1177 / 0265407505047835}$

Whisman, M. A., Gordon, K. C., \& Chatav, Y. (2011). Predicting sexual infidelity in a population-based sample of married individuals. Journal of Family Psychology, 21(2), 320-324. doi: $\underline{10.1037 / 0893-3200.21 .2 .320}$

Widhiarso, W. (2010). Perbedaan pengertian aspek dan dimensi dalam pengembangan alat ukur. Tersedia online, http:// widhiarso.staff.ugm.ac.id/files/widhiar so_2010_-perbedaan_pengertian_ aspek_dan_dimensi_dalam_pengemba ngan_alat_ukur.pdf

Wolfinger, N. H., \& Wilcox, W. B. (2008). Happily ever after? Religion, marital status, gender, and relationship quality in urban families. Social Forces, 86, $1311-1337$.

Wunderer, E., \& Schneewind, K. A. (2008). The relationship between marital standards, dyadic coping and marital satisfaction. European Journal of Social Psychology, 38(3), 462-476.

Xu, X., \& Lai, S.C. (2004). Gender ideologies, marital roles, and marital quality in Taiwan. Journal of Family Issues, 25 (3), 318-335. doi: $\underline{10.1177 / 0192513 X 03257709}$

Zhang, H. (2015). Wives'relatif income and marital quality in urban China: Gender role attitudes as a moderator. Journal of Comparative Family Studies, XLVI (2), 203-220.

Zhang, H., Tsang, S. K. M., Chi, P., Cheung, Y. T., Zhang, X., \& Yip, P. S. F. (2012). Wives' relative income and marital satisfaction among the urban Chinese population: Exploring some moderating effects. Journal of Comparative Family Studies, 43(2), 185-198

Zhang, H., Xu, X., \& Tsang, S. K. M. (2012). Conceptualizing and validating marital quality in Beijing: A pilot study. Social Indicators Research, Published online: 02 June 2012 